\title{
PENERAPAN MODEL PROBLEM BASED LEARNING MELALUI \\ GOOGLE CLASSROOM UNTUK MENINGKATKAN KEAKTIFAN \\ BELAJAR JARAK JAUH MATERI PERMASALAHAN SOSIAL PESERTA DIDIK KELAS XI IPS 2 SMA NEGERI 3 DEMAK
}

Oleh:

Ulin Nafi' $a h^{1}$

\begin{abstract}
Abstrak
Penelitian ini bertujuan untuk meningkatkan keaktifan belajar jarak jauh melalui Google Classroom pada materi permasalahan sosial pada peserta didik kelas XI IPS 2 SMA N 3 Demak melalui penerapan model Problem Based Learning. Penelitian ini menggunakan Teknik Penelitian Tindakan kelas (PTK) dengan prosedur perencanaan, pelaksanaa, observasi, dan refleksi. Subjek penelitian ini adalah peserta didik kelas XI IPS 2 dengan jumlah 34 peserta didik. Teknik pengumpulan data dengan menggunakan observasi dan dokumentasi. Dari hasil penelitian pra siklus melalui indikator keaktifan dalam menjawab pertanyaan dan diskusi kelompok sebesar 35\%. Kemudian meningkat pada siklus I (74\%) dan siklus II (97,1\%). Kesimpulan dari penelitian ini adalah penerapan model Problem Based Learning pada materi Permasalahan Sosial dapat meningkatkan keaktifan belajar jarak jauh peserta didik kelas XI IPS 2 SMA N 3 Demak Tahun Pelajaran 2020/2021.
\end{abstract}

Kata Kunci: Google Classroom, Keaktifan Belajar, Permasalahan Sosial, Problem Based Learning

\footnotetext{
${ }^{1}$ Guru Sosiologi SMA N 3 Demak, email : adindaulin34@ gmail.com
} 



\section{PENDAHULUAN}

Pendidikan menjadi salah satu tolak ukur dalam menentukan kemajuan sebuah Negara. Tujuan pendidikan Indonesia dapat dilihat pada Undang-Undang Nomor 20 Tahun 2003 yang berbunyi "Sistem Pendidikan Nasional adalah untuk mengembangkan potensi peserta didik agar menjadi manusia yang beriman dan bertakwa kepada Tuhan Yang Maha Esa, berakhlak mulia, sehat, berilmu, cakap, kreatif mandiri dan menjadi warga negara yang demokratis serta bertanggung jawab". Demi mencapai tujuan tersebut, pendidikan harus terus berjalan meskipun dalam kondisi pandemic covid.

Pembelajaran pada sekolah zona merah covid-19 dilaksanakan dengan daring atau biasa disebut dengan Pembelajaran Jarak Jauh menuntut guru dan peserta didik menggunakan aplikasi pembelajaran online. SMA Negeri 3 Demak yang berada di wilayah zona merah pandemic covid-19 turut menerapkan pembelajaran dengan jarak jauh dengan platform Google Classroom. Namun, pembelajaran jarak jauh yang dilakukan oleh guru cenderung monoton yang hanya memberikan materi dan tugas lewat Google Classroom sehingga peserta didik jarang terlibat dalam proses pembelajaran. Terlebih pada materi permasalahan sosial yang semestinya peserta didik dapat menganalisis dan merespon masalah sosial di dunia nyata tetapi dalam pelaksanannya peserta didik kurang aktif mengikuti kegiatan pembelajaran. Hal ini dapat dilihat dari hasil penelitian pra tindakan yang menunjukkan keaktifan peserta didik kelas XI IPS 2 hanya 35,3 \% yang termasuk dalam kategori rendah. Keaktifan peserta didik dalam menjawab pertanyaan dari guru sebanyak 14 peserta didik dengan skor rata-rata 1,5 dalam kategori kurang dan sebanyak 9 peserta didik yang aktif melakukan diskusi kelompok dengan ratarata skor 1,3 dengan kategori kurang.

Menurut Melvin L. Silberman (2009:23) "belajar aktif yaitu proses pembelajaran yang meliputi aspek mendengar, melihat mendiskusikan, menerapkan dan mengajarkan kepada orang lain". Indikator keaktifan belajar menurut Harahap dalam Vitasari (2013) meliputi: 1) Merespon motivasi yang diberikan oleh guru; 2) Membaca atau memahami masalah yang terdapat dalam lembar kerja siswa (LKS); 3) menyelesaikan masalah atau menemukan jawaban dan cara untuk menjawab; 4) Mengemukakan pendapat; 5) Berdiskusi atau bertanya antar peserta didik maupun guru; 6) Mempresentasikan hasil kerja kelompok; 7) Merangkum materi yang 
telah didiskusikan. Adapun indikator keaktifan belajar peserta didik yang akan dilakukan dalam penelitian ini adalah: 1)Keaktifan peserta didik dalam menjawab pertanyaanyang diberikan oleh guru dalam forum diskusi; 2) Keaktifan peserta didik dalam diskusi kelompok dengan model Problem Based Learning.

Diperlukan model pembelajaran yang tepat, inovatif dan berpusat pada peserta didik sehingga dapat meningkatkan keaktifan pembelajaran jarak jauh. Salah satu model pembelajaran yang dapat diterapkan adalah model pembelajaran Problem Based Learning. Moffit (dalam Rusman, 2012: 241) mengatakan bahwa "Pembelajaran Berbasis Masalah (Problem Based Learning) merupakan suatu pendekatan pembelajaran yang menggunakan masalah dunia nyata sebagai suatu konteks bagi siswa untuk belajar tentang berpikir kritis dan ketrampilan pemecahan masalah serta untuk memperoleh pengetahuan dan konsep yang esensi dari materi pelajaran".

Pada penelitian yang dilakukan oleh Susilowati (2018), penerapan Model Pembelajaran Problem Based Learning berhasil meningkatkan Keaktifan Belajar siswa pada materi Ekosistem di Kompetensi Keahlian X Otomatisasi dan Tata Kelola Perkantoran SMKN 2 Penajam Paser Utara dengan kategori baik pada siklus I sebesar 74\% dan sangat baik pada siklus II yang mencapai $85 \%$. Hal ini dikuatkan oleh hasil penelitian yang dilakukan oleh Sari (2019) yang menyimpulkan bahwa terdapat peningkatan keaktifan dan hasil belajar siswa SMPN 1 Mayang kelas IX A melalui model pembelajaran Problem Based Learning. Adapun pada penelitian ini membahas tentang keaktifan belajar jarak jauh pada materi permasalahan sosial. Pembelajaran dilaksanakan secara daring menggunakan platform Google Classroom dengan aktivitas sinkron ketika kegiatan pendahuluan dan penutup, sedangkan kegiatan diskusi dilakukan secara asinkron atau tertulis dengan saling membalas lewat kolom komentar.

Berdasarkan latar belakang diatas, maka masalah yang dikaji dalam penelitian ini adalah apakah pembelajaran dengan model Problem Based Learning melalui Google Classroom dapat meningkatkan keaktifan belajar jarak jauh materi permasalahan sosial bagi peserta didik kelas XI IPS 2 SMA N 3 Demak.

Adapun tujuan dari penelitian ini untuk meningkatkan keaktifan belajar jarak jauh melalui Google Classroom pada materi permasalahan sosial peserta didik kelas XI IPS 2 SMA N 3 Demak melalui penerapan model problem based learning. Penelitian ini bermanfaat bagi guru sebagai bahan pertimbangan dalam memilih model pembelajaran yang sesuai dengan 
karakteristik peserta didik, bagi peserta didik dapat meningkatkan keaktifan pembelajaran jarak jauh melalui model Problem Based Learning, serta bagi sekolah dapat memberikan kontribusi terhadap mutu sekolah dan perbaikan dalam bidang Pendidikan.

\section{METODE PENELITIAN}

Penelitian ini dilaksanakan di SMA Negeri 3 Demak pada Tahun Pelajaran 2020/2021 semester ganjil dengan jumlah subyek penelitian 34 peserta didik dari kelas XI IPS 2. Penelitian ini dilaksanakan pada pembelajaran Sosiologi materi permasalahan sosial secara daring (dalam jaringan) menggunakan platform Google Classroom selama tiga pekan.

Penelitian ini merupakan Penelitian Tindakan Kelas (PTK) dengan prosedur menurut Hopkins (1993) yang meliputi perencanaan, pelaksanaan, pengamatan, dan refleksi. Pelaksanaan Tindakan dilakukan selama dua siklus, siklus I dilakukan dua kali pertemuan dan siklus II sebanyak satu kali pertemuan.

Pengumpulan data dilakukan dengan menggunakan instrumen penelitian berupa lembar observasi keaktifan belajar jarak jauh peserta didik kelas XI IPS 2 pada materi permasalahan sosial melalui google classroom dengan model Problem Based
Learning. Validitas data menggunakan validitas konstruk menurut Suryabrata (2000) bahwa validitas konstruk (construct validity) menyatakan sejauh mana skorskor hasil pengukuran dengan suatu instrumen itu merefleksikan konstruk teoretik yang mendasari penyusunan instrumen tersebut. Validitas konstruk penelitian ini dengan mendefinisikan terlebih dahulu tentang keaktifan belajar selanjutnya disiapkan instrumen yang digunakan untuk mengukur keaktifan belajar peserta didik.

\section{HASIL}

\section{Indikator Keberhasilan Tindakan}

Penelitian tindakan kelas ini dikatakan berhasil apabila kriteria keberhasilan telah tercapai. Adapun kriteria keberhasilan tindakan tersebut adalah ketika adanya peningkatan keaktifan belajar peserta didik setelah tindakan pada siklus I dan setelah tindakan pada siklus II. Dengan ketentuan sekurang-kurangnya mencapai skor keaktifan dalam kategori baik, yaitu berada pada kisaran skor $4 \leq$ skor $\leq 6$ dan dengan prosentase keberhasilan $75 \%$.

\section{Analisis Data}

Metode analisis data yang digunakan pada penelitian ini yaitu pada data lembar 
observasi keaktifan peserta didik dianalisis secara deskriptif. Keaktifan peserta didik dideskripsikan dalam bentuk kalimat

$$
\text { Jarak interval }(i)=\frac{8-0}{4}=2
$$

menurut kriteria untuk memperoleh kesimpulan.

Menurut Widyoko (2012:110) Langkahlangkah untuk menentukan klasifikasi berdasarkan skor dapat dilakukan sebagai berikut:

a. Menentukan skor terendah (k)

b. Menentukan skor tertinggi (m)

c. Mencari median (nilai tengah)

d. Mencari jarak interval

e. Membagi rentang nilai menjadi 4 kategori, yaitu sangat baik, baik, cukup, dan kurang.

$$
\text { Median }=\frac{\text { Skor maksimal+skor minimal }}{2}
$$

(Poerwanti, 2008:6.9)

Jarak Skor maksimal

$$
\text { interval }(\mathrm{i})=\quad \frac{\text { skor minimal }}{\text { Jumlah kelas interval }}
$$

Adapun dalam menentukan kriteria skor keaktifan peserta didik diperoleh perhitungan sebagai berikut:

$$
\begin{aligned}
& \mathrm{k}=\text { skor terendah }=0 \times 8=0 \\
& \text { Median }(\mathrm{Me})=\quad 8+0 \quad=4
\end{aligned}
$$

$$
\begin{gathered}
\text { Jarak interval }(i)=\frac{2}{8-0}=2 \\
\mathrm{~m}=\text { skor tertinggi }=1 \times 8=8
\end{gathered}
$$

Dari hasil penghitungan yang telah dilakukan oleh peneliti, maka tabel klasifikasi rata-rata skor keaktifan klasikal tiap siklusnya adalah sebagai berikut:

Tabel 1

Kriteria Ketuntasan Keaktifan Peserta didik

\begin{tabular}{|c|c|}
\hline $\begin{array}{c}\text { Skor Keaktifan } \\
\text { Peserta Didik }\end{array}$ & Kriteria \\
\hline $6 \leq$ skor $\leq 8$ & Sangat Baik \\
\hline $4 \leq$ skor $<6$ & Baik \\
\hline $2 \leq$ skor $<4$ & Cukup \\
\hline $0 \leq$ skor $<2$ & Kurang \\
\hline
\end{tabular}

Klasifikasi kategori nilai untuk setiap indikator Keaktifan peserta didik adalah sebagai berirkut:

Tabel 2

Kriteria Keaktifan Peserta Didik Tiap Indikator

\begin{tabular}{|c|c|}
\hline Skor Keaktifan Siswa & Kriteria \\
\hline $3 \leq$ skor $\leq 4$ & Sangat Baik \\
\hline $2 \leq$ skor $<3$ & Baik \\
\hline $1 \leq$ skor $<2$ & Cukup \\
\hline $0 \leq$ skor $<1$ & Kurang \\
\hline
\end{tabular}

Sedangkan untuk menentukan prosentase keberhasilan dapat dihitung dengan rumus berikut: 


$\mathrm{P}=\frac{\begin{array}{c}\text { Jumlah Nilai Rata-rata } \\ \text { indikator yang } \\ \text { dilaksanakan }\end{array}}{\text { Jumlah indikator }}$ maksimal $100 \%$

\section{Deskripsi Siklus Pra Tindakan}

Kondisi awal sebelum dilakukan penelitian, guru sekaligus peneliti telah melakukan kegiatan pembelajaran pada kelas XI IPS 2 dengan materi masalah sosial yang membahas tentang pengertian dan ciri-ciri masalah sosial. Guru melakukan pembelajaran secara daring melalui platform Google Classroom dengan mengunggah materi kemudian memberikan sejumlah pertanyaan lewat kolom komentar dan memberikan tugas kelompok dengan menyediakan laman untuk diskusi. Pertanyaan dan bahan diskusi yang disajikan oleh guru hanya sebatas materi secara konseptual sehingga peserta didik tidak perlu melakukan diskusi kelompok untuk menemukan jawaban karena dapat mencari jawaban secara mandiri. Berdasarkan pembelajaran tersebut, hasil keaktifan dari peserta didik berupa menjawab pertanyaan guru di forum diskusi dan diskusi kelompok menanggapi argumen dari teman sangat rendah. Keaktifan peserta didik dalam kegiatan pembelajaran sebelum dilakukan tindakan dapat dilihat pada tabel berikut:

Tabel 3

\section{Hasil Pengolahan Data Awal Keaktifan Peserta Didik}

(Sumber: Data Peneliti,2020)

\begin{tabular}{|c|c|c|c|c|c|c|c|c|}
\hline \multirow[t]{2}{*}{ No } & \multirow[t]{2}{*}{ Keaktifan peserta didik } & \multicolumn{4}{|c|}{ Skor } & \multirow{2}{*}{$\begin{array}{c}\text { Jumlah } \\
\text { Skor }\end{array}$} & \multirow{2}{*}{ Rerata } & \multirow{2}{*}{ Kategori } \\
\hline & & 1 & 2 & 3 & 4 & & & \\
\hline 1. & $\begin{array}{l}\text { Menjawab pertanyaan guru } \\
\text { di Google Classroom }\end{array}$ & 20 & 12 & 2 & 0 & 50 & 1,5 & Kurang \\
\hline 2. & $\begin{array}{l}\text { Diskusi kelompok antar } \\
\text { peserta didik di Google } \\
\text { Classroom }\end{array}$ & 25 & 6 & 3 & 0 & 46 & 1,3 & Kurang \\
\hline & Jumlah & & & & & 96 & & \\
\hline & Prosentase keberhasilam & & & & & \multicolumn{2}{|c|}{$35 \%$} & \\
\hline & $\begin{array}{c}\text {-rata skor keaktifan peserta } \\
\text { didik }\end{array}$ & & & & & \multicolumn{2}{|c|}{2,8} & \\
\hline & Kriteria & & & & & \multicolumn{2}{|c|}{ Cukup } & \\
\hline
\end{tabular}

Berdasarkan tabel diatas diketahui bahwa keaktifan peserta didik dalam kegiatan mengikuti forum diskusi dengan menjawab pertanyaan guru sebesar 1,5\% berada pada kategori kurang, sedangkan diskusi antar teman mencapai 1,3\% juga kategori kurang. Selain itu, prosentase keberhasilan hanya mencapai angka 35\% yang masih jauh dari angka keberhasilan minimal $75 \%$.

\section{Deskripsi Hasil Pelaksanaan Tindakan}

\section{Siklus I}

Tindakan siklus I dilakukan dua kali pertemuan pada tanggal 22 Oktober 2020 dan 2 November 2020 dengan waktu 2x 45 menit. Pada kegiatan awal, guru membuka pelajaran dan mengkondisikan kesiapan peserta didik dalam menerima pelajaran. 
Kemudian masuk kegiatan inti dengan mengarahkan peserta didik untuk mengamati video masalah sosial yang sudah diunggah di platform Google Classroom. Guru memberikan pertanyaan kepada peserta didik terkait video yang diamati. Semua peserta didik menjawab pertanyaan dari guru namun kebanyakan masih belum mengaitkan dengan konsep sosiologis. Kegiatan selanjutnya guru mengarahkan peserta didik berdiskusi kelompok dengan saling menanggapi lewat kolom komentar. Pada kegiatan ini, sudah banyak peserta didik yang menanggapi argumen dan memberi solusi pendapat teman lain dengan logis dan benar. Namun, masih terdapat peserta didik yang belum berargumen atau menanggapi argumen peserta didik lain.

Hasil observasi tentang keaktifan belajar jarak jauh materi permasalahan sosial kelas XI IPS 2 melalui Google Classroom dengan model pembelajaran Problem Based Learning siklus I dapat dilihat pada tabel 4.

Tabel 4. Hasil Observasi Keaktifan Peserta Didik Pada Siklus 1

\begin{tabular}{|c|c|c|c|c|c|c|c|c|}
\hline \multirow[t]{2}{*}{ No } & \multirow[t]{2}{*}{ Keaktifan peserta didik } & \multicolumn{4}{|c|}{ Skor } & \multirow{2}{*}{$\begin{array}{c}\text { Jumlah } \\
\text { Skor }\end{array}$} & \multirow{2}{*}{ Rerata } & \multirow{2}{*}{ Kategori } \\
\hline & & 1 & 2 & 3 & 4 & & & \\
\hline 1. & $\begin{array}{l}\text { Menjawab pertanyaan guru } \\
\text { di Google Classroom }\end{array}$ & 0 & 9 & 16 & 9 & 104 & 3,0 & B \\
\hline 2. & $\begin{array}{l}\text { Diskusi kelompok antar } \\
\text { peserta didik di Google } \\
\text { Classroom }\end{array}$ & 7 & 3 & 11 & 13 & 98 & 2,9 & B \\
\hline & Jumlah & & & & & 203 & & \\
\hline & Prosentase keberhasilam & & & & & \multicolumn{2}{|c|}{$74 \%$} & \\
\hline & $\begin{array}{l}\text {-rata skor keaktifan peserta } \\
\text { didik }\end{array}$ & & & & & \multicolumn{2}{|c|}{5,9} & \\
\hline & Kriteria & & & & & \multicolumn{2}{|c|}{ Baik } & \\
\hline
\end{tabular}

(Sumber: Data Peneliti, 2020)

Berdasarkan data lembar observasi pada Tabel 4 dapat diketahui bahwa skor rata-rata keaktifan peserta didik pada siklus I adalah 5,9 dengan prosentase keberhasilan 74\%. Hal ini dapat diartikan rata-rata keaktifan peserta didik dalam memecahkan masalah termasuk dalam kategori ' $\mathrm{B}$ ' yaitu "Baik". Namun prosentase keberhasilan belum mencapai $75 \%$. Hal yang masih belum dicapai dengan maksimal meliputi aspek dalam memahami masalah kasus belum tepat sehingga penyelesaian masalahnya masih kurang tepat dan belum mengaitkan dengan konsep sosiologi. Oleh karena itu masih ada beberapa hal yang masih perlu diperbaiki untuk siklus berikutnya.

\section{Deskripsi Hasil Pelaksanaan Tindakan} Siklus II

Peneliti melaksanakan tindakan pada siklus II pada tanggal 2 November 2020 dengan waktu 2x45 menit di SMA N 3 Demak kelas XI IPS 2 dengan jumlah 34 peserta didik. Adapun langkah-langkah pelaksanaan tindakan pada siklus II diawali dengan guru membuka pelajaran dan mengkondisikan kesiapan peserta didik dalam kegiatan pembelajaran. Kemudian pada kegiatan inti, guru mengarahkan peserta didik untuk mengamati kasus permasalahan sosial dan menjawab pertanyaan terkait permasalahan yang 
diamati. Sebagian besar peserta didik dapat menjawab pertanyaan dari guru dengan tepat, menggunakan bahasa yang komunikatif, dan sudah mengaitkan dengan konsep sosiologis. Kegiatan selanjutnya peserta didik berdiskusi dengan kelompok kecil yang berjumlah 4-5 peserta didik untuk mengefektifkan waktu dan mendapatkan hasil diskusi yang mendalam. Selama diskusi, guru memberikan masukan ketika terdapat argumen yang kurang sesuai sehingga peserta didik dapat memperbaiki argumennya. Sebagian besar peserta didik mampu menanggapi argumen dan memberi solusi pendapat teman lain dengan logis dan benar. Setelah diskusi selesai, guru memberikan apresiasi kepada peserta didik yang sudah mengikuti pembelajaran dengan baik dan memberikan reward.

Tabel 5 Hasil observasi keaktifan peserta didik pada siklus II.

\begin{tabular}{|c|c|c|c|c|c|c|c|c|}
\hline \multirow[t]{2}{*}{ No } & \multirow{2}{*}{$\begin{array}{c}\text { Keaktifan peserta } \\
\text { didik }\end{array}$} & \multicolumn{4}{|c|}{ Skor } & \multirow{2}{*}{$\begin{array}{r}\text { Jumlah } \\
\text { Skor }\end{array}$} & \multirow[b]{2}{*}{ Rerata } & \multirow[b]{2}{*}{ Kategori } \\
\hline & & 1 & 2 & 3 & 4 & & & \\
\hline 1. & $\begin{array}{l}\text { Menjawab pertanyaan } \\
\text { guru di Google } \\
\text { Classroom }\end{array}$ & 2 & 0 & 1 & 31 & 129 & 3,8 & SB \\
\hline 2. & $\begin{array}{l}\text { Diskusi kelompok } \\
\text { antar peserta didik di } \\
\text { Google Classroom }\end{array}$ & 0 & 0 & 1 & 33 & 135 & 3,97 & SB \\
\hline & Jumlah & & & & & 264 & & \\
\hline & osentase Keberhasilan & & & & & & & \\
\hline & $\begin{array}{l}\text { a-rata skor keaktifan } \\
\text { peserta didik }\end{array}$ & & & & & & & \\
\hline & Kriteria & & & & & & Baik & \\
\hline
\end{tabular}

(Sumber: Data Peneliti,2020)

Berdasarkan data lembar observasi pada tabel diatas dapat diketahui bahwa skor rata-rata keaktifan peserta didik pada siklus II adalah 7,8 dengan prosentase keberhasilan $97,1 \%$. Hal ini dapat diartikan rata-rata keaktifan peserta didik dalam memecahkan masalah termasuk dalam kategori "SB' yaitu "Sangat Baik" dan sudah mencapai prosentase keberhasilan. Peserta didik sudah mampu memahami permasalahan dalam kasus dan mencari alternatif pemecahan masalahnya dengan tepat dan mengaitkan dengan konsep sosiologi.

Peningkatan keaktifan belajar jarak jauh peserta didik kelas XI IPS 2 menggunakan Google Classroom pada materi permasalahan sosial dengan model Problem Based Learning dapat dilihat pada diagram berikut:

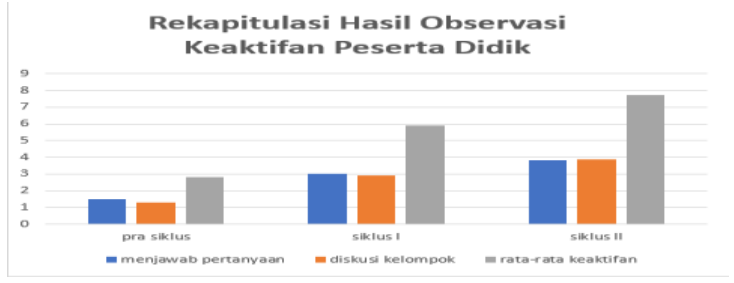

Gambar 1: Diagram rekapitulasi keaktifan peserta didik (Sumber : Data Peneliti, 2020)

Berdasarkan diagram diatas dapat dilihat perbandingan keaktifan peserta didik dari pra siklus menuju ke siklus I dan II yang mengalami peningkatan. Pencapaian skor keaktifan peserta didik pada pra siklus hanya 2,8 dengan kategori cukup kemudian mencapai 5,9 pada siklus 
I dalam kategori baik dan mencapai kategori sangat baik pada siklus II yakni 7,8. Oleh karena itu, tindakan yang dilakukan berhasil mencapai indikator yang berada pada kisaran skor $4 \leq$ skor $\leq 6$.

Sedangkan prosentase keberhasilan tindakan dapat digambarkan pada diagram berikut:

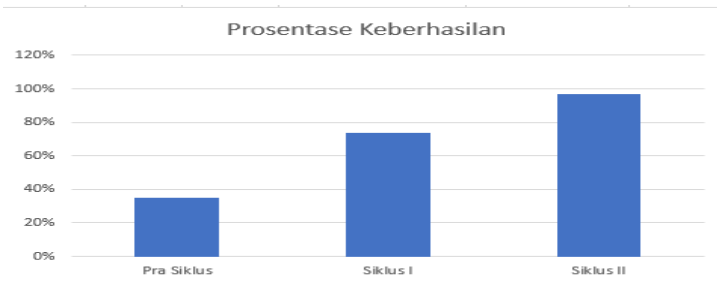

Gambar 2 : Prosentase keberhasilan tindakan

(Sumber : peneliti, 2020)Diagram diatas menunjukkan adanya peningkatan prosentase keberhasil tindakan pada tiap siklusnya.

Keberhasilan tindakan pra siklus hanya $35 \%$, kemudian terjadi peningkatan prosentase keberhasilan dari siklus I ke siklus II sebesar $23,1 \%$ yaitu dari skor $74 \%$ pada siklus I meningkat menjadi $97,1 \%$ pada siklus II. Dengan demikian, prosentase keberhasilan sudah mencapai indikator ketercapaian yang ditentukan yaitu $75 \%$.

\section{DISKUSI}

Pelaksanaan pembelajaran model Problem Based Learning mampu meningkatkan keaktifan belajar karena memberikan kesempatan penuh bagi peserta didik untuk menjadi pembelajar yang aktif. Hasil penelitian yang telah dilakukan menunjukkan adanya peningkatan keaktifan belajar jarak jauh pada siklus I diperoleh skor rata-rata 5,9 dengan prosentase keberhasilan 74,6\% yang termasuk dalam kriteria baik meskipun belum mencapai prosentase keberhasilan yang ditentukan. Kemudian mengalami peningkatan pada siklus II dengan rata-rata skor 7,77 dan prosentase keberhasilan mencapai $97,1 \%$ termasuk dalam kriteria sangat baik.

Pada kegiatan orientasi masalah, peserta didik melakukan pengamatan pada kasus permasalahan sosial baik melalui video maupun teks berita kemudian menjawab pertanyaan yang diberikan guru terkait permasalahan yang diamati secara mendiri dengan mengaitkan pengetahuan yang dimiliki. Selanjutnya, peserta didik melakukan diskusi untuk memecahkan permasalahan sosial dan diakhiri dengan saling mengeroksi hasil diskusi antar kelompok. Hal ini sejalan dengan pendapat Melvin L. Silberman (2009: 23) yang mengatakan bahwa "belajar aktif yaitu proses pembelajaran yang meliputi aspek mendengar, melihat, mendiskusikan, menerapkan dan mengajarkan kepada orang lain". Oleh karena itu, pembelajaran dengan model Problem Based Learning menjadi efektif untuk meningkatkan keaktifan belajar jarak jauh peserta didik pada materi permasalahan sosial.

\section{KESIMPULAN}

Berdasarkan hasil penelitian yang 
telah dilakukan dapat disimpulkan bahwa penerapan model Problem Based Learning pada materi Permasalahan Sosial dapat meningkatkan keaktifan belajar jarak jauh peserta didik kelas XI IPS 2 SMA N 3 Demak Tahun Pelajaran 2020/2021. Hal ini dapat dibuktikan dengan pencapaian skor keaktifan yang mencapai 5,9 dalam kategori baik pada siklus I dan mencapai
7,8 pada siklus II dengan kategori sangat baik. Kemudian peningkatan keaktifan peserta didik kelas XI IPS 2 pada penelitian siklus I sebesar $74 \%$ meningkat $23,1 \%$ menjadi $97,1 \%$ pada siklus II.

\section{Daftar Pustaka}

Hopkins, David. (1993). A Teacher's Guide to Classroom Research. Philadelphia: Open University Press.

Muslich, Mansur. (2009). Melaksanakan PTK itu Mudah. Jakarta: PT. Bumi Aksara

Poerwanti, Endang, dkk. (2008). Asesmen Pembelajaran SD. Jakarta: Dirjen Dikti.

Rusman. (2014). Model-model Pembelajaran : Mengembangkan Profesionalisme Guru. Jakarta: PT Rajagrafindo Persada.

Sari, Rohmah Juwita. (2019). Peningkatan Keaktifan Siswa dan Hasil Belajar dengan Menggunakan Metode Pembelajaran Problem Based Learning Pada Siswa SMPN 1 Mayang Kelas IX. Jurnal Pendidikan IPA. Vol II (1). garuda.ristekbrin.go.id

Silberman, Melvin L. (2009). Active Learning. Bandung: Nusamedia.

Suryabrata, S. (2000). Pengembangan Alat Ukur Psikologis. Yogyakarta: Andi Offset.

Susilowati. (2018). Penerapan Model Pembelajaran Problem Based Learning untuk Meningkatkan Keaktifan Belajar Siswa pada Materi Ekosistem di Kompetensi Keahlian X Otomatisasi dan Tata Kelola Perkantoran SMKN 2 Penajam Paser Utara Tahun Pelajaran 2017/2018. Jurnal Kompetensi. Vol. 11 (2). garuda.ristekbrin.go.id UU Republik Indonesia nomor 20 tahun 2003. Sistem Pendidikan Nasional. 2003. Bandung: Sinar Grafika.

Vitasari, Rizka. (2013). Peningkatan Keaktifan dan Hasil Belajar Matematika Melalui Model Problem Based Learning Siswa Kelas V SD Negeri 5 Kutosari. Kalam Cendekia PGSD Kebumen. Vol. 4(3):2. garuda.ristekbrin.go.id

Widoyoko, S. Eko Putro. (2012). Teknik Penyusunan Instrumen Penelitian. Yogyakarta: Pustaka Pelajar. 